\title{
Early reactivation of ischaemia after abrupt discontinuation of heparin in acute myocardial infarction
}

\author{
Giuseppe Di Tano, Antonio Mazzù
}

\begin{abstract}
Intravenous heparin after thrombolytic therapy for acute myocardial infarction is an effective, widely used treatment. Six cases of acute myocardial infarction are reported with early disease reactivation following the abrupt discontinuation of heparin infusion three days after alteplase thrombolysis and concomitant aspirin therapy. Immediate reinfusion of heparin resulted in regression of symptomatic ischaemia in all six patients. The activated partial thromboplastin time values, determined four hours before the discontinuation of heparin therapy, were within the therapeutic range in five of the six patients, and no difference was found in the values obtained one hour after the reinfusion of heparin $(P=0.065)$.
\end{abstract}

(Br Heart f 1995;74:131-133)

Keywords: myocardial infarction; heparin; ischaemia; thrombolytic treatment.

The strategy of the best antithrombotic therapy following systemic thrombolysis in the subacute phase of myocardial infarction remains an unsettled issue. Intravenous heparin in conjunction with alteplase improves coronary patency ${ }^{12}$ and prevents coronary reocclusion. ${ }^{13}$ The duration of the heparin infusion for optimum results is, however, unknown. ${ }^{4}$

We report here on six patients treated with alteplase for acute myocardial infarction with early disease reactivation following abrupt heparin discontinuation. Reintroduction of heparin reversed the deterioration in all six patients.

\section{CASE REPORT}

The report involves six non-consecutive male admissions to our coronary care unit for acute myocardial infarction (five with anterior infarction and one with inferior infarction) within 4.98 (SD 0.73 ) hours of symptom onset. These six patients were the only ones among 140 consecutive admissions with acute myocardial infarction to develop reactivation of disease following treatment. There was therefore a $4.3 \%$ incidence of reactivation. Mean age was $60(7 \cdot 0)$ years and body weight $71 \cdot 5(2 \cdot 6) \mathrm{kg}$. No previous ischaemic episodes and no smoking history were recorded.

All received systemic thrombolytic therapy with alteplase (rt-PA, $100 \mathrm{mg}$ in $3 \mathrm{~h}$, given as a
$10 \mathrm{mg}$ bolus, followed by $50 \mathrm{mg}$ over $1 \mathrm{~h}$ and $40 \mathrm{mg}$ over $2 \mathrm{~h}$ ), a glyceryl trinitrate infusion, and aspirin $160 \mathrm{mg}$ daily. The first dose of aspirin was given at the onset of the thrombolysis. An intravenous heparin infusion $(1000 \mathrm{U} / \mathrm{h})$, preceded by a bolus injection of $5000 \mathrm{U}$, was started after completion of the alteplase infusion, and was titrated to maintain the activated partial thromboplastin time at 1.5-2 times the baseline values. It was routinely discontinued after three days. Before withdrawal of heparin all patients were symptom-free, and no angina or silent ischaemia was recorded. At $28 \cdot 3(5 \cdot 1)$ minutes after the abrupt discontinuation of heparin (range 20-35 minutes), chest pain developed acutely in all six patients, with new ischaemic electrocardiographic changes in the leads originally involved. Prompt reintroduction of the heparin, $2500 \mathrm{U}$ as a bolus followed by 1000 $\mathrm{U} / \mathrm{h}$ infusion, resulted in rapid regression of pain and ST changes after $9 \cdot 1(1 \cdot 8)$ minutes. No secondary increase in plasma creatine kinase values was observed and no patients experienced recurrent angina at a later time.

The table shows the activated partial thromboplastin time values four hours before the discontinuation of heparin (within the therapeutic range in five of the six patients) and one hour later (within the therapeutic range in all six patients). The difference was not statistically significant, at $50(9 \cdot 7) v 54.3$ $(5 \cdot 0) \mathrm{s}, \mathrm{P}=0.065$.

\section{Discussion}

This report describes an unusual observation: early ischaemic reactivation after discontinuation of heparin infusion in patients with acute myocardial infarction treated with a thrombolytic agent. Previous reports have described this only in patients with unstable angina. ${ }^{56}$ The finding has important clinical implications because the number of patients at risk of an ischaemic recurrence is considerably increased if we also include the population with acute myocardial infarction.

In our cases the rebound occurred very early $(28 \cdot 3(5 \cdot 1)$ minutes) following discontinuation of the heparin infusion, with a narrow time range among all six patients (20-35 minutes), and in spite of an activated partial thromboplastin time within the therapeutic range in five of the six patients and the concomitant use of aspirin. Prompt reintroduction of the heparin infusion resolved the ischaemic reactivation phenomenon in all six patients. 
Clinical data of patients and activated partial thromboplastin time values determined $4 h$ before the discontinuation and 1 h after the reinfusion of heparin

\begin{tabular}{|c|c|c|c|c|c|c|c|c|c|c|c|c|c|}
\hline $\begin{array}{l}\text { Patient } \\
\text { No }\end{array}$ & $\begin{array}{l}\text { Age } \\
\text { (years) }\end{array}$ & Sex & $\begin{array}{l}\text { Weight } \\
(\mathrm{kg})\end{array}$ & $\begin{array}{l}\text { Site of } \\
A M I\end{array}$ & $\begin{array}{l}\text { Symptom } \\
\text { onset } \\
\text { (h) }\end{array}$ & $\begin{array}{l}\text { Thrombolytic } \\
\text { agent }\end{array}$ & $\begin{array}{l}\text { Peak } \\
C K \\
(I U / l)\end{array}$ & $\begin{array}{l}\text { Indirect } \\
\text { markers of } \\
\text { reperfusion } \\
\text { (pain, CK, ST) }\end{array}$ & $\begin{array}{l}\text { Time of pain } \\
\text { onset after } \\
H \text { suspension } \\
\text { (min) }\end{array}$ & $\begin{array}{l}\text { ECG } \\
\text { changes } \\
(\mathrm{mm})\end{array}$ & $\begin{array}{l}\text { Time to relief } \\
\text { of pain after } \\
\text { H reinfusion } \\
\text { (min) }\end{array}$ & $\begin{array}{l}\text { APTT } T^{*} \\
4 h \text { before } \\
\text { (s) }\end{array}$ & $\begin{array}{l}A P T T^{*} \\
1 \text { h after } \\
\text { (s) }\end{array}$ \\
\hline $\begin{array}{l}1 \\
2 \\
3 \\
4 \\
5 \\
6\end{array}$ & $\begin{array}{l}56 \\
64 \\
58 \\
66 \\
68 \\
48\end{array}$ & $\begin{array}{l}M \\
M \\
M \\
M \\
M \\
M\end{array}$ & $\begin{array}{l}75 \\
73 \\
72 \\
68 \\
72 \\
69\end{array}$ & $\begin{array}{l}\text { Anterior } \\
\text { Anterior } \\
\text { Anterior } \\
\text { Inferior } \\
\text { Anterior } \\
\text { Anterior }\end{array}$ & $\begin{array}{l}6 \\
5 \cdot 30 \\
4 \\
4 \cdot 30 \\
5 \cdot 30 \\
5\end{array}$ & $\begin{array}{l}\text { Alteplase } \\
\text { Alteplase } \\
\text { Alteplase } \\
\text { Alteplase } \\
\text { Alteplase } \\
\text { Alteplase }\end{array}$ & $\begin{array}{r}1800 \\
2400 \\
890 \\
940 \\
1874 \\
1025\end{array}$ & $\begin{array}{l}\text { Yes } \\
\text { Yes } \\
\text { Yes } \\
\text { Yes } \\
\text { Yes } \\
\text { Yes }\end{array}$ & $\begin{array}{l}30 \\
20 \\
25 \\
30 \\
35 \\
30\end{array}$ & $\begin{array}{l}\mathrm{ST} \uparrow 1.5 \\
\mathrm{ST} \uparrow 2 \cdot 0 \\
\mathrm{ST} \uparrow 1.5 \\
\mathrm{ST} \uparrow 2 \cdot 0 \\
\mathrm{ST} \uparrow 3.0 \\
\mathrm{ST} \uparrow 2.0\end{array}$ & $\begin{array}{r}12 \\
8 \\
10 \\
10 \\
8 \\
7\end{array}$ & $\begin{array}{l}52 \\
52 \\
48 \\
56 \\
60 \\
32\end{array}$ & $\begin{array}{l}54 \\
56 \\
51 \\
60 \\
60 \\
45\end{array}$ \\
\hline
\end{tabular}

AMI, acute myocardial infarction; CK, plasma creatine kinase; H, heparin; APTT, activated partial thromboplastin time; ST $\uparrow$, ST segment elevation. $\star P=0.065$ (NS)

Heparin infusion therapy is recommended in patients with acute myocardial infarction and other acute coronary syndromes. ${ }^{347}$ However the optimal duration, correct dosage, procedure for discontinuing the intravenous infusion, and what to do about recurrent chest pain and ST changes have not been established. ${ }^{4}$

In a recent clinical study, Théroux et $a{ }^{5}$ reported the reactivation of unstable angina in a clustered pattern, 9.5 (5) hours after discontinuation of infusion in 14 of 107 patients receiving heparin alone. Concomitant therapy with aspirin markedly reduced the incidence and severity of reactivation events. More recently, Gold et al described a rebound coagulation phenomenon occurring five to eight hours after cessation of the infusion of argatroban, a selective thrombin inhibitor, in nine out of 43 patients with unstable angina.

Our observation differs from these reports and may be useful in elucidating the mechanisms of the rebound phenomenon. One would not expect a major reduction in the activated partial thromboplastin time within 30 minutes of the discontinuation of heparin. However, by this time the heparin concentration had probably decreased to a suboptimal level, with the loss of some of its protective effect. These data show that activated partial thromboplastin time monitoring may not be optimal for assessing the biological efficacy of heparin, as suggested by Melandri et al. ${ }^{8}$ In this latter study, the activated clotting time correlated better with blood heparin concentration than the activated partial thromboplastin time. It may also be more rewarding to examine markers of in vivo thrombin generation. However, in clinical practice the objective of obtaining adequate anticoagulation may be facilitated by the use of a standard heparin nomogram, ${ }^{9}$ recently weight adjusted and improved by Becker et al. ${ }^{10}$

Our study also shows that aspirin may not provide adequate protection against rebound ischaemia, considering that the aspirin effect is limited to one pathway of platelet aggregation and does not affect thrombin induced platelet aggregation. The clot-bound thrombin which is unaffected by heparin may elicit a thrombogenic process that can persist for many days in some patients. ${ }^{11}$ Upon heparin withdrawal, plasma inhibition may rapidly decrease, and the trapped thrombin reactivates the thrombogenic process, leading to recurrent ischaemia. ${ }^{12}$ In this regard, Miller et $a l^{13}$ have recently observed a rebound increase in thrombin activity, with recurrent ischaemia, after abrupt cessation of heparin infusion in patients with acute ischaemic syndromes.

In conclusion, whatever the mechanism underlying this early rebound phenomenon, we feel that it is more than a chance finding. The following points may be helpful in the management of patients with acute myocardial infarction treated with thrombolysis in conjunction with intravenous heparin. (1) Reactivation of disease may be clinically important and the patients should be carefully evaluated following the discontinuation of heparin. (2) Recurrence of chest pain following cessation of heparin, despite concomitant therapy with aspirin, can be effectively controlled by re-infusion of heparin, without the need for additional thrombolytic therapy. (3) Alternative methods of heparin withdrawal should be considered to avoid this event. Intravenous heparin, continued for a minimum of four to five days, should be gradually withdrawn instead of abruptly stopped, and (4) there should be overlapping subcutaneous administration at least two hours before the infusion is discontinued. ${ }^{14}$

Further studies are needed to increase our understanding of this problem and to determine whether newer, more potent, and more specific inhibitors of thrombin will overcome the reactivation phenomenon.

We thank Dr Pierre Theroux for critical review of the manuscript.

1 Arnout J, Simoons M, De Bono D, Rapold HJ, Collen D, Verstraete M. Correlation between level of heparinization and patency of the infarct-related coronary artery tion and patency of the infarct-related coronary artery after treatment of acute myocardial infarction

2 Hsia J, Kleiman N, Aguirre F, Chaitman BR, Roberts R, Ross AM. Heparin-induced prolongation of partial thromboplastin time after thrombolysis: relation to coronary artery patency. $\mathcal{f} \mathrm{Am}$ Coll Cardiol 1992;20:31-5.

3 Hsia J, Hamilton WP, Kleiman N, Roberts R, Chaitman BR, Ross AM. A comparison between heparin and lowdose aspirin as adjunctive therapy with tissue plasminogen activator for acute myocardial infarction. $N \mathrm{Engl} ₹ \mathrm{Med}$ 1990;323:1433-7.

4 Conti CR. Heparin after unstable angina, myocardial infarction and coronary artery angioplasty: when and how should the drug be stopped? (editor's note). Clin how should the drug be

5 Theroux P, Waters D, Lam J, Juneau M, McCans J. Reactivation of unstable angina after the discontinuation Reactivation of unstable angina after the disco
of heparin. $N$ Engl f Med 1992;327:141-5.

6 Gold HK, Torres FW, Garabedian HD, Werner W, Jang I, Khan A, et al. Evidence for a rebound coagulation phenomenon after cessation of a 4-hour infusion of a specific thrombin inhibitor in patients with unstable angin pectoris. F Am Coll Cardiol 1993;21:1039-47.

7 Hirsh J. Heparin. N Engl f Med 1991;324:1565-74.

8 Melandri G, Branzi A, Traini AM, Semprini F, Cervi V, Magnani B. On the value of the activated clotting time for monitoring heparin therapy in acute coronary syndromes. Am 7 Cardiol 1993;71:469-70.

9 Cruickshank MK, Levine MN, Hirsh J, Roberts R, 
Siguenza M. A standard heparin nomogram for the management of heparin therapy. Arch Intern Med 1991; 151:333-7.

10 Becker RC, Corrao JM, Ball SP, Gore JM. A comparison of heparin strategies after thrombolytic therapy. Am Heart $\mathcal{F}$ 1993;126:750-2.

11 Weitz JI, Hudoba M, Massel D, Maraganore J, Hirsh J. Clot-bound thrombin is protected from inhibition by heparin-antithrombin III but is susceptible to inactivation by antithrombin III-independent inhibitors. $\mathcal{f}$ Clin tion by antithrombin
Invest 1990;86:385-91.
12 Chesebro JH, Badimon L, Fuster V. New approaches to treatment of myocardial infarction. Am $\mathcal{F}$ Cardiol 1990; 65:12-19C.

13 Miller J, Granger C, Bovill E, Krucoff M, Berrios E, Harrington R, et al. Rebound increase in thrombin activity after cessation of intravenous heparin (abstract). Circulation 1993;88(suppl 1):202a.

14 Chesebro JH, Badimon JJ, Fernandez Ortiz A, Meyer BJ, Fuster V. Conjunctive antithrombotic therapy for thrombolysis in myocardial infarction. Am 7 Cardiol 1993;72:66-74G. 